\author{
Maciej Grochowski \\ Polska Akademia Nauk \\ Instytut Języka Polskiego \\ magro@umk.pl \\ Maciej Grochowski \\ Polish Academy of Sciences \\ Institute of Polish Language \\ magro@umk.pl
}

\title{
SZYK LEKSEMÓW HOMONIMICZNYCH O POSTACI JAK
}

\section{THE ORDER OF THE POLISH HOMONYMIC LEXEMES IN THE SHAPE OF JAK}

W artykule wyróżnia się jedenaście homonimicznych leksemów jednosegmentowych o postaci jak. Reprezentują one różne klasy i podklasy gramatyczne jednostek leksykalnych. Artykuł zawiera wstępny opis pozycji linearnych badanych leksemów. Główne tezy autora są następujące. Szyk jak-leksemów w zdaniach jest zdeterminowany strukturalnie i jest stały. Każdy jak-leksem występuje w antepozycji do zdania prostego lub podrzędnego albo przed tym składnikiem zdania, z którym wchodzi w relację syntaktyczną. na, szyk.

Słowa klucze: współczesny język polski, składnia, części mowy, jednostka leksykal-

In the paper eleven one-segmental homonymic lexemes in the shape of the Polish jak are distinguished. They represent the different grammatical classes and subclasses of lexical units. The paper contains a preliminary description of the linear positions of the examined lexemes. The main author's theses are the following. The order of the jak-lexemes in the Polish sentences is structurally determined and it is stable. Each jak-lexeme appears in the anteposition to either the simple or the subordinate sentence or before the sentence component with which jak-lexeme enters into syntactic relation. order.

Keywords: contemporary Polish language, syntax, parts of speech, lexical unit, word

\section{Szyk i jego uwarunkowania}

Składnia bada reguły łączenia wyrażeń językowych w konstrukcje, a więc w grupy syntaktyczne i zdania. Łączenie odbywa się na płaszczyźnie znaczeniowej i formalnej. W ten sposób dochodzi do powstawania struktur pojęciowych i struktur znakowych (Karolak 1984: 14; 2002: 149). Formy wyrażeń językowych 
są w jakiś sposób, nie dowolny, usytuowane względem siebie. Reguły ich wzajemnej lokalizacji, zdeterminowanej funkcjonalnie, ustala składnia linearna. Jeżeli przyjmie się za Stanisławem Karolakiem $(1972 ; 1984 ; 2002)$ stratyfikacyjną koncepcję składni, to można przyjąć za nim rozróżnienie trzech poziomów opisu syntaktycznego, a mianowicie składnię semantyczną, składnię funkcjonalną i składnię szyku (inaczej: linearną).

Pojęcie szyku jest rozumiane w sposób szeroki lub wąski. W pierwszym wypadku jest ono używane w odniesieniu do związków linearnych dwustronnych i wielostronnych, a także do samej pozycji linearnej wyrażenia językowego. W drugim wypadku szykiem jest nazywany tylko stosunek dwustronny, a więc stosunek następstwa / uprzedniości zachodzący między dwoma obiektami językowymi. W odniesieniu do związków wielostronnych, a więc określających kolejność, w jakiej występują poszczególne obiekty językowe wewnątrz obiektu wyższego rzędu (bardziej złożonego), jest używane wówczas pojęcie porządku linearnego. Pojęcie szyku jest tutaj rozumiane w sposób wąski.

Szyk w języku polskim jest zdeterminowany częściowo strukturalnie, częściowo komunikacyjnie. Przez uwarunkowanie strukturalne rozumiem zależność pozycji linearnej danego wyrażenia od związków składniowych sensu largo, w jakie ono wchodzi (zarówno formalnych, jak i funkcjonalnych) z innymi komponentami wypowiedzenia i z samym wypowiedzeniem, a także od relacji semantycznych między tym wyrażeniem a innymi. Na pozycję linearną zdeterminowaną przez kod mówiący nie ma wpływu i respektuje ją pod groźbą dewiacji. Uwarunkowanie strukturalne szyku jest charakterystyczne dla wielu klas jednostek gramatycznych. Np. przyimek występuje w antepozycji względem rzeczownika, którym rządzi; zaimek względny który występuje w postpozycji w stosunku do rzeczownika, z którym wchodzi w relację; operator negacji o postaci nie występuje w bezpośredniej antepozycji względem wyrażenia, do którego się odnosi.

Uwarunkowania komunikacyjne szyku zależą od woli mówiącego, który chce o czymś coś komuś powiedzieć, mając do dyspozycji określone środki językowe. Mówiący ma możliwość kształtowania szyku tylko w takim zakresie, w jakim pozwala na to kod, a więc nie naruszając danych a priori ograniczeń strukturalnych. Najbardziej ogólna zasada przekazywania informacji, wykorzystująca porządek linearny jako narzędzie mówienia, polega na tym, że mówiący umieszcza w bezpośrednim sąsiedztwie takie obiekty językowe, których kookurencja jest umotywowana treściowo. Krótko rzecz ujmując, szyk w języku polskim jest jednym ze sposobów kształtowania i reprezentacji struktury tematyczno-rematycznej wypowiedzenia.

\section{Przedmiot i metody badań}

Przedmiotem tego artykułu jest opis szyku polskich jednostek leksykalnych o postaci jak. Wyróżniony ciąg należy do grupy wyrazów o wysokiej frekwencji w tekstach języka polskiego. W Słowniku frekwencyjnym polszczyzny współcze- 
snej (red. Saloni 1990: 802) na liście rangowej według wskaźnika częstości absolutnej $F$ zajmował pozycję 18. Ciąg jak jest częścią setek wielosegmentowych jednostek leksykalnych; por. np. jak Boga kocham, jak diabli, jak gdyby, jak jeden mą̇, jak nic, jak nieboskie stworzenie, jak nie kijem go, to patka. Konstytuuje też samodzielnie kilkanaście jednostek, w niniejszym artykule zostało wyróżnionych arbitralnie jedenaście, będzie o nich mowa w kolejnych częściach tekstu.

Przyjmuję założenie, że jednostki leksykalne tożsame diakrytycznie (fonologicznie i grafemicznie), a różniące się cechami gramatycznymi (w wypadku jednostek nieodmiennych, syntaktycznymi), tworzą zbiór homonimów gramatycznych (Buttler 1968; 1988; Dąbkowski 2012; Grochowski 1986a; 2014; Majewska 2002; 2006). Aksjomat ten odnoszę do analizowanych tu jednostek o postaci jak. Słowniki języka polskiego opisują jak, łącząc homonimię z polisemią. Nie ma dwóch słowników współczesnej polszczyzny (od SJPD począwszy), które wyróżniły tę samą liczbę jednostek i znaczeń jak, abstrahując już od różnic między kwalifikatorami gramatycznymi jednostek, a także między definicjami ich znaczeń bądź funkcji. Nawet Jolanta Chojak (2009), autorka monografii poświęconej jak, z dystansem podchodzi do opisów słownikowych. Ma krytyczny stosunek do podziałów gramatycznych jednostek o postaci jak, opartych na kryteriach dystrybucyjnych (Kallas 1986; 1987), sama nie proponuje jednak zamkniętego katalogu jednostek homonimicznych. Koncentruje uwagę na słowie jak pełniącym funkcję wykładnika porównania, a także wprowadzającym zdanie zależne na pozycję otwieraną przez czasownik konstytuujący zdanie nadrzędne.

Literatura na temat leksemów o kształcie jak jest ogromna, co stanowi naturalną konsekwencję zróżnicowania funkcji, jakie mogą pełnić leksemy o tej postaci. Jednostki leksykalne konstytuowane przez jak są charakteryzowane w pracach dotyczących porównania (Bańko 2004; Chojak 2009; Greszczuk 1988; Wierzbicka 1971; Zaucha 2008; 2010), czasowników percepcyjnych (Chojak 2008; 2009; Dobaczewski 2002; Grzesiak 1983), parentezy (Moroz 2010; Stępień 2014), jednostek funkcyjnych, zwłaszcza zaimków i spójników (Ampel 1975; Chojak 2005; 2009; Grochowski 1984; 1986b; Kallas 1986; 1987; Łojasiewicz 1991; 1992).

Ponieważ celem tego artykułu jest zbadanie pozycji linearnej jak, a przekonująca jest hipoteza, że szyk jak jest zdeterminowany strukturalnie, to zgodnie z przyjętymi założeniami badań szyku trzeba najpierw ustalić właściwości gramatyczne jednostek o postaci jak. W związku z tym przyjmuję tu następujące zasady postępowania badawczego. Na podstawie słowników języka polskiego i literatury językoznawczej wyróżniam jednosegmentowe leksemy homonimiczne o postaci jak, ustalam ich cechy składniowe, przede wszystkim otwierane przez te leksemy pozycje syntaktyczne i nałożone na nie ograniczenia. Nie analizuję leksemów o postaci jak z punktu widzenia ich mono- i polisemii. Biorąc pod uwagę dotychczasowe klasyfikacje gramatyczne leksemów języka polskiego, proponuję kwalifikację gramatyczną wyróżnionych jednostek. Nie kieruję się jednak założeniami żadnej klasyfikacji, nie akceptuję żadnych rozpowszechnionych podziałów. Leksemy o postaci jak mają liczne cechy jednostkowe bądź cechy charakterystyczne dla kilkuelementowych serii. 
W tym artykule wyróżniam i badam jedenaście jednostek o postaci jak. Oznaczam je arbitralnie kolejnymi cyframi arabskimi. Związek między cyfrą a kwalifikatorem gramatycznym nie ma żadnej motywacji. Jeżeli nie widzę możliwości zakwalifikowania danej jednostki do żadnej ze znanych klas gramatycznych, to proponuję nową klasę lub nową podklasę w obrębie znanej klasy. Przyjmując, że szyk jest zależnością relacyjną, ustalam pozycję linearną każdej jednostki w stosunku do wypowiedzenia i/lub składnika wypowiedzenia mających określone cechy gramatyczne. Do dominujących właściwości linearnych jak należą antepozycja względem wypowiedzenia lub jego składnika, a także interpozycja w wypowiedzeniu lub w grupie syntaktycznej.

\section{Leksemy o postaci jak}

Jak1 jest zaimkiem pytajnym. Otwiera obligatoryjnie prawostronnie jedną pozycję syntaktyczną dla innego syntaktemu albo dla wypowiedzenia; wraz $\mathrm{z}$ odpowiednią intonacją konstytuuje pytanie. Por. np.

(1) Jak dojechałeś do dworca?

(2) Jak długo jechałeś do dworca?

(3) Jak on ma na imię?

(4) Jak w szkole? Pamiętaj, że za rok matura. (NKJP)

Jak 1 zajmuje stałą pozycję inicjalną w wypowiedzeniu i zarazem antepozycję względem innych jego składników; mogą to być składniki gramatycznie różne, ich kwalifikacja nie jest relewantna dla kwalifikacji gramatycznej jak jako zaimka (może być relewantna dla opisu znaczenia jak, ale problem ten nie należy do zakresu tego artykułu).

Jak2 jest relatorem. Ten rozpowszechniony dziś w składni polskiej termin zaproponowałem w klasyfikacji leksemów (Grochowski 1986b: 46), żeby w szerszej klasie jednostek łączących przeciwstawić takie, które są składnikami zdań (relatory), takim, które nie mają tej cechy (spójniki). Po uściśleniu tego terminu przyjmuję dziś (Grochowski et al. 2018: 193), że relator to syntaktem zajmujący pozycję składnika wypowiedzenia zależnego, otwierający prymarnie dwustronnie pozycje syntaktyczne, przyłączający z lewej strony wypowiedzenie główne (niezależne) lub jego składnik, a z prawej strony wypowiedzenie zależne (podrzędne). Por. np.

(5) Zatańcz, jak chcesz.

(6) Będą głosować, jak im księża każą.

(7) Dziesięć lat minęło, jak się rodzice rozwiedli.

Relator jak 2 występuje zawsze w antepozycji względem wypowiedzenia podrzędnego, prymarnie w interpozycji względem wypowiedzeń składowych wypowiedzenia złożonego, sekundarnie w antepozycji względem całego wypowiedzenia złożonego. W tym drugim wypadku w wypowiedzeniu nadrzędnym może wystąpić zaimek nazywany w składni tradycyjnej „odpowiednikiem zespolenia" (Klemensiewicz 1963: 73); np. tak, to w:

(8) Jak im księża każą, tak będą głosować. 
(9) Jak się rodzice rozwiedli, to dziesięć lat minęło.

Relator jak 2 jest przypuszczalnie bi- lub polisemiczny, w wyniku analizy semantycznej można wyróżnić m.in. relator sposobu (5), (6) i relator czasu (7).

Jak3 jest włącznikiem. Włącznik to syntaktem otwierający dwie pozycje syntaktyczne, prawostronną dla wypowiedzenia zależnego (podrzędnego) i lewostronną dla wypowiedzenia nadrzędnego, konstytuowanego przez predykat z komponentem semantycznym 'mówić', 'wiedzieć' lub 'chcieć'. Włączniki (że, żeby, czy, jak, jakoby) zostały wydzielone z klasy spójników przez Jadwigę Wajszczuk (1997: 39-46). Nazwa też pochodzi od autorki, przyjęła się w składni polskiej ostatnich dwudziestu lat. Wybór włącznika nie jest dowolny, zależy od znaczeń wyrażeń tworzących obustronny kontekst. Por. jak $3 \mathrm{np}$. w:

(10) Córka opowiadała, jak wyglądał jej egzamin.

(11) Piotr czuł, jak łzy napływają mu do oczu.

(12) Widziałem, jak przed chwilą weszła do sklepu.

Jak 3 występuje w antepozycji względem wypowiedzenia podrzędnego i z reguły w interpozycji w stosunku do wypowiedzenia złożonego. Nie jest wykluczone, że jak 3 po czasownikach mówienia i po czasownikach percepcji ma inne znaczenie (tak jest opisywany ten wyraz w wielu słownikach). Problem wymaga osobnych badań.

Jak4 jest spójnikiem niewłaściwym. Przyjmuję tu koncepcję spójnika autorstwa Jadwigi Wajszczuk (1997) i zaproponowany przez nią podział tej klasy jednostek na spójniki właściwe i niewłaściwe. Spójnik to parataktem otwierający dwustronnie pozycje dla innych wyrażeń, nienacechowany semantycznie ani strukturalnie (Grochowski et al. 2018: 192). Spójnik właściwy (np. i, a, oraz, ale, $l e c z, l u b, a l b o, c z y, a n i, b o, g d y z$ ) występuje wyłącznie w interpozycji względem wyrażeń, dla których otwiera miejsca. Spójnik niewłaściwy (np. byle, choć, chociaż, gdyby, jak, jakby, jeżeli, jeśli, ponieważ, skoro) zajmuje pozycję centralną lub początkową względem łączonych wyrażeń. Inaczej mówiąc występuje zawsze $\mathrm{w}$ antepozycji względem wypowiedzenia podrzędnego i w interpozycji w stosunku do wypowiedzeń składowych wypowiedzenia złożonego. Może zajmować pozycję inicjalną w wypowiedzeniu złożonym. Por. jak $4 \mathrm{np}$. w:

(13) Zostanę, jak będziesz chciała.

(14) Na pewno wyjechał, jak nie dzwoni.

Jednostka jak 4 jest przypuszczalnie niejednoznaczna, w (13) ma znaczenie 'jeżeli', a w (14) — znaczenie 'skoro'; por. Grochowski 1984. Problem wymaga odrębnych badań.

Jak5 to funktor porównania. Źródłem tego terminu, pochodzącego z monografii Chojak (2009: 91), jest klasyfikacja dystrybucyjna syntaktemów Henryka Misza (1967: 57), który nazwał jak ,funktorem porównującym”. Por. jak 5 np. w:

(15) Krzyczał jak opętany.

(16) Huk był jak sto diabłów.

(17) Ciemno jak w dupie u Murzyna.

(18) Miło jak w raju.

(19) Barack Obama jest jak Britney Spears. 
Dla wyróżnienia jak 5 proponowano także inne terminy, mianowicie przyimek (Kallas 1986: 129), spójnik (Bogusławski 1989: 22; Kallas 1986: 129), określnik metatekstowy (Zaucha 2010: 118). Pierwszy jest nieadekwatny w odniesieniu do takich porównań, których drugi człon nie podlega rekcji; por. np. (17), (18). Spójnik w teorii Wajszczuk (2010) jest parataktemem, teza ta pozostaje w konflikcie z jak w konstrukcjach porównawczych, zajmującym określoną pozycję syntaktyczną, a więc będącym składnikiem wypowiedzenia. Określniki metatekstowe (Wajszczuk 1997: 53) nakładają na otwierane pozycje relewantne ograniczenia kategorialne, cechy tej nie ma leksem jak 5, dopuszczający odwołanie nawet do imion własnych; por. np. (19). Ze znanych mi propozycji terminologicznych najlepsza jest pochodząca od Misza (1967) oraz Chojak (2009) i przyjęta w tym artykule.

Jak 5 otwiera dwie pozycje syntaktyczne, jedną po jednej stronie jednostki, drugą po drugiej. W pozycji pierwszej występuje przymiotnik, rzeczownik, czasownik lub przysłówek, a w drugiej grupa nominalna bezprzyimkowa lub przyimkowa. Jednostka jak 5 zajmuje obligatoryjnie antepozycję względem drugiego członu porównania, a tym samym interpozycję w stosunku do obu członów. Jeżeli omawiana jednostka jest użyta w kontekście komparatywu przymiotnika lub przysłówka, to występuje względem tej formy stopnia w postpozycji, analogicznie do $n i z ;$ np.

(20) Nie mógł jej unieść wyżej jak do pasa. (WSJP)

(21) Z kolei na Sobieskiego roboty nie zaczną się szybciej jak 23-24 września. (WSJP)

Jak6 nazywam — na podstawie analizy Jolanty Chojak (2001: 80-83) komentarzem metatekstowym quasi-przytoczenia. Sama autorka nie proponuje żadnego terminu, który byłby kwalifikatorem semantyczno-syntaktycznym jak 6, występującego w stałej antepozycji w stosunku do superlatywu przymiotnika i przysłówka. Por. przykłady autorki:

(22) Szukamy jak najkrótszej drogi.

(23) Weź jak najdłuższy sznurek.

(24) Mam o niej jak najlepszą opinię.

Komentarz metatekstowy, analogicznie do partykuły i spójnika, jest parataktemem (Wajszczuk 2010), to znaczy wchodzi z wyrażeniem, dla którego otwiera miejsce, w związek składniowy polegający na kookurencji, a nie na zależności (jak syntaktem). Komentarze są stosunkowo słabo zbadane, nie mają ustalonej kategorialnie pozycji w strukturze tematyczno-rematycznej (Danielewiczowa 2012: 58; Grochowski et al. 2018: 192).

Wbrew definicjom słownikowym jak 6 nie jest wykładnikiem intensywności i nie może być uznany za operator gradacji (por. WSJP, jak w zn. 7). O tym, że dany obiekt ma cechę w ilości większej niż wszystkie pozostałe obiekty, przesądza sam superlativus (Laskowski 1977). Natomiast mówiący umieszczając jak $6 \mathrm{w}$ antepozycji względem superlatywu, wskazuje na swój świadomy wybór (Chojak 2001: 83; Wierzbicka 1969: 187) tego, co przytoczona forma stopnia głosi. Stąd taka, a nie inna propozycja kwalifikatora gramatycznego jak 6 . Nie 
w każdym wypowiedzeniu zawierającym superlativus można użyć jak 6. Chojak wyjaśnia szczegółowe ograniczenia semantyczne nałożone na kontekst tego leksemu. Świadomego wyboru nie może dokonać np. pies, stąd dewiacja

(25) *Pies szuka jak najkrótszej drogi do domu. (Chojak 2001: 81)

Nieakceptowalne są również konstatacje, które nie zawierają podmiotu osobowego, a także takie, które nie wskazują na udział woli osoby w jej zachowaniu; por. np.

(26) *To kosztowało jak najdrożej. (Chojak 2001: 81)

(27) *Przez przypadek odsunął się jak najdalej. (Chojak 2001: 81)

Jak7 jest modyfikatorem deklaratywności. Termin ten zaproponowałem w klasyfikacji leksemów nieodmiennych (Grochowski 1986b: 50), aby wyróżnić jednostki mające łączliwość silnie ograniczoną indywidualnie, występujące w wypowiedzeniach innych niż oznajmujące, kształtujące ramę modalną wypowiedzenia. Jak 7 występuje w pozycji inicjalnej wypowiedzenia, otwiera prawostronnie pozycję dla co najmniej jednego syntaktemu i wraz z nim oraz odpowiednią intonacją przekształca wypowiedzenie oznajmujące w wykrzyknikowe. Por. np.

(28) Jak tu pięknie!

(29) Jak się cieszę, że przyszedłeś!

(30) Jak ona mówi po francusku!

W jednym ze znaczeń jak 7 , nieakcentowane, jest „zwrotem wyrażającym to, że mówiący jest pod wrażeniem stanu rzeczy, o którym mówi” (Chojak 2001: 84) W tym znaczeniu omawiana jednostka ogranicza formy czasownika do trybu orzekającego (por. WSJP, jak w zn. 8). W innym znaczeniu z kolei jak 7, akcentowane, występuje w antepozycji względem czasownika dokonanego (w czasie nieprzeszłym), na ogół zanegowanego (Bogusławski - Danielewiczowa 2005: 113); por. np.

(31) Jak nie huknie pięścią w stół, aż się szklanki zatrzęsły!

(32) Jak nie podskoczy do tego chłopczyny, jak go nie wyrżnie w buzię. (NKJP)

(33) Jak nie wypadnie jego stara, jak go nie trzaśnie w pysk. (NKJP)

Jak8 to komentarz metatekstowy parentetyczny. Do omówionej wcześniej pierwszej części terminu (por. jak 6) został dodany atrybut „parentetyczny”. Badania nad parentezą, prowadzone od wielu dziesięcioleci (por. np. Grochowski 1983, Moroz 2010, Stępień 2014), pozwalają na podtrzymanie rozpowszechnionej tezy o jej metatekstowym statusie.

Jednostka jak 8 otwiera prawostronnie pozycję syntaktyczną dla wyrażenia zdaniowego parentetycznego, konstytuowanego przez formę czasownika mówienia lub czasownika epistemicznego, i zajmuje stałą antepozycję względem parentezy. Szyk parentezy względem wypowiedzenia podstawowego jest zmienny, w związku z tym zmienna jest też względem niego pozycja linearna jak 8. Szczegółową analizę składniową i semantyczną parentezy wprowadzanej przez jak przedstawiła Marzena Stępień (2014: 90-143). Por. przykłady autorki: 
(34) Sąsiad, jak przypuszczam, wyjechał na cały rok.

(35) Maria, jak się zdaje, jest osobą samotną.

(36) Radzisz sobie, jak widzę, znakomicie.

(37) Czas jest, jak wiadomo, najlepszym lekarstwem.

Jak9 to komentarz metatekstowy wyliczenia. Termin ten został utworzony na zasadzie analogii do wcześniejszych; por. jak 6 i jak 8. Omawiana jednostka otwiera dwie pozycje syntaktyczne, po obu swoich stronach, $\mathrm{z}$ lewej strony dla nazwy zbioru, do którego należą elementy wymienione po prawej stronie, z prawej strony dla tych elementów. Jak 9 występuje w interpozycji w stosunku do łączonych wyrażeń i zarazem w antepozycji względem członów wyliczenia (Grochowski 1978). Jednostkę jak 9 może poprzedzać zaimek taki. Por. np.

(38) Inne dłuższe rzeki biorące początek w strefie pojeziernej, jak Wkra, Orzyc, Omulew, Osa, Ełk i Pisa, kończą bieg poza zasięgiem opisywanego terenu. (WSJP)

(39) Nie istnieje człowiek pozbawiony nie tylko więzi pokoleniowej, ale i więzi z instytucjami, takimi jak państwo, szkoły, sądy, fabryki, biura i sklepy. (NKJP)

(40) Nie potrafił już mówić o niczym innym, jak o rolnictwie, zasiewach, zbiorach, nawozach, kombajnach oraz snopowiązałkach. (NKJP)

Jak10 to komentarz metatekstowy epistemiczny. Termin został utworzony na zasadzie analogii do wcześniejszych, por. jak 6, jak 8, jak 9. Jednostka jak 10 otwiera po obu swoich stronach po jednej pozycji syntaktycznej, którą wypełnia ta sama forma rzeczownikowa. Inaczej mówiąc, jak 10 występuje w interpozycji, a zarazem w antepozycji względem drugiego członu. Do wprowadzonego w ten sposób przez interlokutora tematu wypowiedzi nawiązuje mówiący, dodając swój komentarz. Por. np.

(41) Miasto jak miasto, są w okolicy dużo ładniejsze. (NKJP)

(42) Facet jak facet, nie ma ideałów i ty o tym wiesz. (NKJP)

(43) Ślub jak ślub, a co z wieczorem kawalerskim? (NKJP)

(44) Boronów, wieś jak wieś, gmina jak gmina. Ani mała, ani duża. (WSJP)

Podobna jednostka dwuelementowa o postaci _, jak_, ale_została wyróżniona w pracy Bogusławski — Danielewiczowa (2005: 112); por. przykład autorów:

(45) Córka jak córka, ale mamusia! Z tej dopiero jest artystka.

Analogiczną strukturę składniową ma jedna z jednostek konstytuowanych przez_nie_(Grochowski 2007: 276); por. np.

(46) Strach nie strach, ale iść do dentysty musisz.

Jak11 nazywam operatorem metaleksykalnym. Por. np.

(47) O jak Olga, S jak Stefan, A jak ananas.

Omawiana jednostka otwiera dwie pozycje syntaktyczne, lewa jest wypełniona przez literę, a prawa przez wyraz zaczynający się od tej litery, obie wielkości są więc użyte w supozycji materialnej. Jak 11 występuje w interpozycji, a zarazem w antepozycji w stosunku do wyrazu, do którego mówiący się odwołuje. 


\section{Podsumowanie}

W systemie leksykalnym współczesnej polszczyzny da się wyodrębnić n jednostek o postaci jak, reprezentujących różne klasy gramatyczne. Liczba tych jednostek jest dyskusyjna, ponieważ nie ma jednej akceptowalnej klasyfikacji gramatycznej leksemów. Dotyczy to przede wszystkim tej części klasyfikacji, która obejmuje jednostki funkcyjne. Im głębsze badania, tym większa pokusa wyróżnienia większej liczby klas.

Wszystkie wyróżnione w tym artykule jednostki jednosegmentowe o postaci jak (jest ich jedenaście) mają szyk uwarunkowany strukturalnie. Zgodnie z przyjętym tu rozumieniem szyku każda jednostka o postaci jak ma szyk stały w stosunku do swojego kontekstu gramatycznego. Jest to szyk antepozycyjny względem wypowiedzenia zależnego (por. np. jak 2, jak 3, jak 4) lub składnika wypowiedzenia, do którego jednostka się odnosi ( jak 6). Nie jest możliwa zmiana szyku samego jak. Jeżeli ulega zmianie szyk wyrażenia wprowadzanego przez jak (względem obiektu odniesienia tego wyrażenia), to zmiana ta obejmuje również tę jednostkę (por. np. jak 2, jak 4, jak 8).

Porównywanie dwóch wielkości należy do inwariantnych funkcji wielu (ale nie wszystkich!) leksemów o postaci jak. Szyk tych jednostek (por. np. jak 5, jak 9, jak 10, jak 11) może być określony również jako interpozycyjny. Z kolei w wypowiedzeniu prostym wprowadzanym przez jak jednostka ta zajmuje stałą pozycję inicjalną (por. np. jak 1, jak 7).

\section{BIBLIOGRAFIA}

Ampel Teresa. Wypowiedzenia okolicznikowe profrazowe we wspótczesnym języku polskim. Rzeszów: WSP, 1975.

Bańko Mirosław. Stownik porównań. Warszawa: PWN, 2004.

Bogusławski Andrzej. „Uwagi o pracy nad frazeologią”. Saloni Zygmunt (red.). Studia z polskiej leksykografii współczesnej III. Białystok: Filia UW, 1989: 13-30.

Bogusławski Andrzej, Danielewiczowa Magdalena. Verba polona abscondita. Sonda słownikowa III. Warszawa: ILS UW, 2005.

Buttler Danuta. „Problematyka badań nad homonimią”. Przeglad Humanistyczny 3 (1968): 57-79.

Buttler Danuta. „Problemy leksykograficznego opisu homonimów”. Rozprawy Komisji Językowej ETN 1-2 (1988): 51-67.

Chojak Jolanta. „Przysłówek — nie przysłówek, modulant — nie modulant. Uwagi na marginesie opisu leksykograficznego jak". Chrakovskij Viktor S., Grochowski Maciej, Hentschel Gerd (red.). Studies on the Syntax and Semantics of Slavonic Languages. Oldenburg: BIS, 2001: $77-87$.

Chojak Jolanta. „Kłopotliwy przysłówek jak”. Grochowski Maciej (red.). Przysłówki i przyimki. Studia ze sktadni i semantyki języka polskiego. Toruń: UMK, 2005: 71-84.

Chojak Jolanta. „O znaczeniu czasownika brzmieć”. Grzegorczykowa Renata, Waszakowa Krystyna (red.). Pojęcie. Stowo. Tekst. Warszawa: UW, 2008: 207-221.

Chojak Jolanta. Zrozumieć ,jak”. Studium składniowo-semantyczne. Warszawa: Wydział Polonistyki UW, 2009.

Danielewiczowa Magdalena. „O pewnym ważnym typie informacji leksykograficznej nieobecnej w słownikach”. Problemy frazeologii europejskiej IX (2012): 51-62.

Dąbkowski Grzegorz. „Homonimia w najnowszych słownikach języka polskiego”. Zdunkiewicz-Jedynak Dorota (red.). Słowa i ich opis. Na drogach wspótczesnej leksykologii. Warszawa: Wydział Polonistyki UW, 2012: 123-130. 
Dobaczewski Adam. Zjawiska percepcji wzrokowej. Studium semantyczne. Warszawa: Katedra Lingwistyki Formalnej UW, 2002.

Greszczuk Barbara. Konstrukcje porównawcze i ich rozwój w języku polskim. Rzeszów: WSP, 1988.

Grochowski Maciej. „Wprowadzenie do opisu wyliczenia jako zasady budowy tekstu”. Pamiętnik Literacki LXIX/3 (1978): 131-147.

Grochowski Maciej. „Metatekstowa interpretacja parentezy”. Dobrzyńska Teresa, Janus Elżbieta (red.). Tekst $i$ zdanie. Zbiór studiów. Wrocław: Ossolineum, 1983: 247-258.

Grochowski Maciej. „Składnia wyrażeń polipredykatywnych (zarys problematyki)”. Topolińska Zuzanna (red.). Gramatyka wspótczesnego języka polskiego. Sktadnia. Warszawa: PWN, 1984: 213-299.

Grochowski Maciej. „Polifunkcyjność gramatyczna jednostek leksykalnych a ich homonimia (z punktu widzenia współczesnej leksykografii)". Prace Filologiczne XXXIII (1986a): 35-42.

Grochowski Maciej. Polskie partykuły. Składnia, semantyka, leksykografia. Wrocław: Ossolineum, 1986b.

Grochowski Maciej. „O kwalifikacji gramatycznej jednostek o postaci nie”. Kamper-Warejko Joanna, Kulwicka-Kamińska-Joanna, Nowakowska Katarzyna (red.). Z przeszłości i teraźniejszości języka polskiego. Księga pamiątkowa dedykowana Teresie Friedelównie. Toruń: UMK, 2007: 271-279.

Grochowski Maciej. „Kryteria opozycji homonimicznych partykuł i przysłówków”. Slavica Wratislaviensia CLIX (2014): 141-148.

Grochowski Maciej, Kisiel Anna, Żabowska Magdalena. „Zasady opisu jednostek funkcyjnych w WSJP PAN". Żmigrodzki Piotr et al. (red.). Wielki słownik języka polskiego PAN. Geneza, koncepcja, zasady opracowania. Kraków: IJP PAN, 2018: 191-204.

Grzesiak Romuald. Semantyka i składnia czasowników percepcji zmysłowej. Wrocław: Ossolineum, 1983.

Kallas Krystyna. „Syntaktyczna charakterystyka wielofunkcyjnego JAK”. Polonica XII (1986): 127-143.

Kallas Krystyna. „Status gramatyczny wyrażeń by i że w połączeniu z wielofunkcyjnym jak”. Saloni Zygmunt (red.). Studia z polskiej leksykografii współczesnej II. Białystok: Filia UW, 1987: $129-150$.

Karolak Stanisław. Zagadnienia składni ogólnej. Warszawa: PWN, 1972.

Karolak Stanisław. „Składnia wyrażeń predykatywnych”. Topolińska Zuzanna (red.). Gramatyka współczesnego języka polskiego. Składnia. Warszawa: PWN, 1984: 11-211.

Karolak Stanisław. Podstawowe struktury składniowe języka polskiego. Warszawa: Instytut Slawistyki PAN, 2002.

Klemensiewicz Zenon. Zarys sktadni polskiej. Warszawa: PWN, 1963.

Laskowski Roman. „Od czego lepszy jest lepszy?”. Język Polski LVII/5 (1977): 323-335.

Łojasiewicz Anna. „O pewnym typie użyć spójnika jak”. Sambor Jadwiga, Huszcza Romuald (red.). Prace z językoznawstwa ogólnego i kontrastywnego. Warszawa: UW, 1991: 65-71.

Łojasiewicz Anna. Własności składniowe polskich spójników. Warszawa: UW, 1992.

Majewska Małgorzata. Homonimia i homonimy w opisie językoznawczym. Warszawa: Wydział Polonistyki UW, 2002.

Majewska Małgorzata. Rzeczownikowe homonimy heterogeniczne. Analiza synchroniczna i diachroniczna. Kraków: IJP PAN, 2006.

Misz Henryk. Opis grup syntaktycznych dzisiejszej polszczyzny pisanej. Bydgoszcz: BTN, 1967.

Moroz Andrzej. Parenteza ze składnikiem czasownikowym we współczesnym języku polskim. Toruń: UMK, 2010.

NKJP: Narodowy korpus języka polskiego [on-line] <www.nkjp.pl> [cit. 18-05-2021].

Saloni Zygmunt (red.). Stownik frekwencyjny polszczyzny współczesnej. Kraków: IJP PAN, 1990.

SJPD: Słownik języka polskiego. Doroszewski Witold (red.). Warszawa: Wiedza Powszechna - PWN, 1958-1969.

Stępień Marzena. Wyrażenia parentetyczne w strukturze wypowiedzi - właściwości semantyczne, sktadniowe, prozodyczne. Warszawa: Wydział Polonistyki UW, 2014.

Wajszczuk Jadwiga. System znaczeń w obszarze spójników polskich. Wprowadzenie do opisu. Warszawa: Katedra Lingwistyki Formalnej UW, 1997. 
Wajszczuk Jadwiga. „Functional class (so called „,part of speech”) assignment as a kind of meaning-bound word syntactic information". Cognitive Studies / Études Cognitives 10 (2010): $15-33$.

Wierzbicka Anna. Dociekania semantyczne. Wrocław: Ossolineum, 1969.

Wierzbicka Anna. „Porównanie — gradacja - metafora”. Pamiętnik Literacki LXII/4 (1971): 127-147.

WSJP PAN: Wielki słownik języka polskiego. Żmigrodzki Piotr (red.). Instytut Języka Polskiego PAN, Kraków 2007, [on-line] <http://www.wsjp.pl> [cit. 18-05-2021].

Zaucha Joanna. „O motywacji rzeczownikowych składników porównań standardowych”. Grzegorczykowa Renata, Waszakowa Krystyna (red.). Pojęcie. Stowo. Tekst. Warszawa: UW, 2008: 241-253.

Zaucha Joanna. Przymiotnikowe wyrażenia porównawcze typu ,głodny jak wilk” we współczesnej polszczyźnie. Warszawa: Wydział Polonistyki UW (rozprawa doktorska), 2010.

\section{Маћеј Гроховски}

\section{РЕД РЕЧИ КОД ХОМОНИМНИХ ЛЕКСЕМА У КОНСТРУКЦИЈАМА ЈАК}

\section{Резиме}

У чланку се издваја једанаест једносегментних хомонимних лексема у конструкцијама jak. Оне представљају различите граматичке класе и поткласе лексичких јединица. Чланак садржи уводни опис линеарних позиција проучаваних лексема. Главне ауторове тезе су следеће. Ред речи jak-лексема је структурно дефинисан и константан. Свака jak-лексема јавља се у антепозицији спрам просте или зависне реченице, односно испред оног реченичног елемента са којим улази у синтаксички однос. речи.

Кључне речи: савремени пољски језик, синтакса, врсте речи, лексичка јединица, ред 